\title{
EVALUASI PERLAKUAN PERSEDIAAN BARANG DAGANGAN PADA PT. PERTANI (PERSERO) CABANG SULAWESI UTARA
}

\author{
Dei Gustiani Gerungan ${ }^{1}$, Sifrid S. Pangemanan², Rudy J. Pusung ${ }^{3}$ \\ 1.2.3 Fakultas Ekonomi dan Bisnis, Jurusan Akuntansi, Universitas Sam Ratulangi, Jl. Kampus Bahu, Manado, \\ 95115, Indonesia \\ E-mail : d_gerungan@yahoo.com
}

\begin{abstract}
PT. Pertani (Persero) Branch of North Sulawesi is a trading company operating in agriculture sector. Inventory has an important role to maintain the company's operational stability and determine the company's level of profit. The main problem in accounting of inventory the inconsistency with PSAK no.14.The purpose of this study is to analysis the consistency between the disclosure of inventory with PSAK no.14. Data was collected by interview, documentation, and initial observation prior research. This study is a qualitative descriptive research. Result show that the company has mostly closure its inventories in accordance with PSAK no. 14.
\end{abstract}

Keywords: inventory accounting, psak no.14

\section{PENDAHULUAN \\ Latar Belakang}

Persediaan memegang peran penting dalam perusahaan, terutama dalam perusahaan dagang. Dalam perusahaan dagang, persediaan hanya terdiri dari satu jenis yaitu persediaan barang dagangan yang merupakan barang yang dibeli dengan tujuan untuk dijual kembali. Dalam perusahaan manufaktur persediaan dibagi menjadi empat jenis persediaan, yaitu persediaan bahan baku, persediaan bahan penolong, persediaan dalam proses, dan persediaan barang jadi. Sedangkan pada perusahaan jasa persediaan yang di perlukan tergantung pada jasa yang dijualnya. Istilah persediaan (inventory) umumnya di tujukan pada barang - barang yang dimiliki perusahaan untuk dijual dalam operasi bisnis normal atau dikonsumsi dalam memproduksi barang yang akan dijual. Pengukuran persediaan biasanya membutuhkan kecermatan karena investasi dalam persediaan merupakan aktiva lancar paling besar dari perusahaan dagang.

Pada dasarnya persediaan mempermudah jalannya operasi perusahaan yang dilakukan secara berturut-turut untuk memproduksi barang-barang serta menyampaikan kepada pelanggan. Persediaan barang dagang merupakan kunci utama dalam jenis usaha dagang. Jika diibaratkan, persediaan merupakan kebutuhan primer dalam jenis usaha dagang. Dapat dikatakan demikian, karena ketika terjadi masalah dalam persediaan, maka akan terganggu pula kegiatan operasional perusahaan.

Terkadang dalam penerapannya, perlakuan persediaan belum dilakukan dengan baik oleh perusahaan karena beberapa faktor, diantaranya kekurangan informasi terhadap metode persediaan terbaru, kurangnya pengetahuan dari pihak perusahaan untuk menerapkan metode yang layak, ataupun perusahaan sudah merasa cocok dengan metode yang digunakan selama ini sehingga mereka takut jika mengganti dengan metode yang baru akan sulit untuk menyesuaikan dengan sistem yang telah diterapkan oleh perusahaan selama ini (Anwar dan Karamoy,2014).

Pengukuran yang diterapkan oleh perusahaan juga tidak semuanya sesuai dengan ketentuan yang berlaku sebagaimana yang mengacu pada Standar Akuntansi Keuangan yang 
berlaku di Indonesia pada Pernyataan Standar Akuntansi Keuangan (PSAK) No.14 dijelaskan tentang perlakuan persediaan.

Berdasarkan latar belakang tersebut, penulis tertarik untuk mengetahui secara lebih dalam bagaimana PT. Pertani (Persero) Cabang Sulawesi Utara mengelolah persediaannya karena persediaan memiliki peran yang sangat penting bagi perusahaan, oleh sebab itu maka penulis tertarik untuk mengangkat hal tersebut dalam sebuah karya tulis ilmiah dalam bentuk skripsi dengan judul "Evaluasi Perlakuan Persediaan Barang Dagangan Pada PT. Pertani (Persero) Cabang Sulawesi Utara”. Tujuan dilakukannya penelitian ini adalah untuk mengetahui perlakuan persediaan barang dagangan pada PT. Pertani (Persero) Cabang Sulawesi Utara sudah sesuai dengan PSAK No. 14.

\section{TINJAUAN PUSTAKA}

Akuntansi

Mardiasmo (2014:20) mengatakan akuntansi dapat dijelaskan dari serangkaian kegiatan pencatatan, penggolongan, peringkasan, dan pelaporan transaksi keuangan suatu perusahaan, dengan cara-cara tertentu yang sistematis. Adapun pengertian dari Rudianto (2012:4) Akuntansi adalah sebuah sistem informasi yang menghasilkan informasi keuangan kepada pihak-pihak yang berkepentingan mengenai aktivitas ekonomi dan kondisi suatu perusahaan.

\section{Akuntansi Keuangan}

Akuntansi keuangan adalah cabang akuntansi yang informasinya lebih dititikberatkan untuk memenuhi kebutuhan pihak intern perusahaan (Mardiasmo 2014:6). Adapun menurut (Pontoh 2013:2) Akuntansi keuangan merupakan bidang akuntansi yang menyediakan informasi akuntansi secara umum bagi para pemakai atau pengambil keputusan yang ada diluar organisasi. Informasi akuntansi keuangan dihasilkan berdasarkan Prinsip Akuntansi yang Berlaku Umum (PABU) atau Generally Accepted Accounting Principles (GAAP).

\section{Konsep Laporan Keuangan}

Laporan keuangan adalah menyajikan secara wajar dan sesuai dengan prinsip akuntansi yang berlaku umum mengenai posisi keuangan, hasil usaha dan perubahan lain dalam posisi keuangan (Hery 2013:15). Sedangkan dalam Standar Akuntansi Keuangan dijelaskan bahwa tujuan laporan keuangan adalah menyediakan informasi yang menyangkut posisi keuangan, kinerja, serta perubahan posisi keuangan suatu perusahaan yang bermanfaat bagi sejumlah besar pemakai dalam pengambilan keputusan ekonomi.

\section{Persediaan}

Persediaan merupakan salah satu aktiva yang paling aktif dalam operasi kegiatan perusahaan dagang. Persediaan juga merupakan aktiva lancar terbesar dari perusahaan manufaktur maupun dagang. Pengaruh persediaan terhadap laba lebih mudah terlihat ketika kegiatan bisnis sedang berfluktuasi (Hery 2013:224). Ikatan Akuntansi Indonesia (2012:14.06) mengemukakan bahwa:

Persediaan adalah aset:

a. Tersedia untuk dijual dalam kegiatan usaha biasa

b. Dalam proses produksi untuk penjualan tersebut; atau

c. Dalam bentuk bahan atau perlengkapan untuk digunakan dalam proses produksi atau pemberian jasa. 


\section{Jenis - Jenis Persediaan}

Santoso (2010:240) menyatakan pengelompokan persediaan didasarkan pada jenis perusahaannya. Bagi perusahaan dagang (merchandise enterprise) dimana persediaan merupakan barang yang langsung diperdagangkan tanpa mengalami proses lanjutan, maka persediaan disebut sebagai persediaan barang dagangan (merchandise inventory). Sedangkan pada perusahaan industry dimana persediaan bahan baku memerlukan proses lebih lanjut agar siap dijual dalam bentuk barang jadi (finishes goods), maka persediaan dikelompokkan menjadi bahan baku, barang dalam proses, barang jadi, dan bahan pembantu.

\section{Biaya Persediaan}

Biaya persediaan terdiri dari seluruh biaya pembelian, biaya konversi, dan biaya lain yang timbul sampai persediaan berada dalam kondisi dan lokasi saat ini (IAI 2012:14.10).

\section{Sistem Pencatatan Persediaan}

1. Sistem pencatatan perpetual

Dalam sistem perpetual, catatan mengenai harga pokok dari masing-masing barang dagangan yang dibeli maupun yang dijual diselenggarakan secara terperinci. Sistem pencatatan ini akan secara terus menerus menunjukkan berapa besarnya saldo persediaan barang dagangan yang ada di gudang untuk masing-masing jenis persediaan. Dengan sistem pencatatan perpetual, hargga pokok dari barang yang dijual ditentukan setiap kali penjualan terjadi (Hery 2013:101).

2. Sistem pencatatan periodik

Sri Dewi Anggadini (2012:226) menjelaskan pencatatan fisik/periodik (phisical/periodic inventory) merupakan pencatatan persediaan dimana:

a. Mutasi persediaan tidak mengunakan buku besar (inventory) melainkan memakai perkiraan purchases, purchases return, sales, sales return dan sebagainya

b. Tidak memakai kartu persediaan

c. Kalkulasi biaya persediaan dengan menetapkan persediaan akhir telebih dahulu melalui perhitungan secara fisik selanjutnya dihitung cost of good sold.

\section{Metode Penilaian Persediaan}

Menurut Santoso (2010 : 248) ada beberapa macam metode penilaian persediaan yang umum digunakan, yaitu :

1. Last-in, First-out (LIFO)

Metode ini didasarkan pada asumsi bahwa himpunan harga pokok yang terakhir akan dibebankan sebagai harga pokok barang yang dijual, dengan demikian niai persediaan yang akan disajikan pada neraca merupakan himpunan biaya (cost) yang berasal dari pembelian-pembelian yang pertama.

2. First-in, First-out (FIFO)

Berdasarkan asumsi ini harga pokok yang harus dibebankan sebagai harga pokok barang yang dijual adalah himpunan harga pokok yang berasal dari pembelian-pembelian yang paling awal, dengan demikian nilai persediaan akan berasal dari himpunan harga pokok yang berasal dari pembelian-pembelian terakhir.

3. Average Cost (Biaya Rata-Rata)

Metode ini didasarkan pada suatu asumsi bahwa nilai persediaan akhir merupakan himpunan harga pokok rata-rata dari persediaan itu sendiri, sehingga baik nilai persediaan maupun harga pokok barang yang dijual selalu akan mempunyai bagian yang sama terhadap harga pokok yang terhimpun dari persediaan tersebut. Dalam sistem persediaan terus - menerus, asumsi ini dikenal dengan istilah metode rata - rata bergerak (moving average method) karena harga pokok per unit akan selalu berubah setiap terjadi mutasi 
dalam persediaan. Sedangkan berdasarkan sistem periodik metode ini dikenal dengan istilah metode harga pokok rata -rata tertimbang (weighted average cost method).

4. Identifikasi Khusus (Specific Identifications)

Dalam metode ini penilaian dilakukan berdasarkan identifikasi barang masing-masing, karena itu dalam prakteknya penerapan metode ini tidak mudah dilakukan dan apabila ditinjau dari segi pengelolaannya pun biasanya manfaat yang didapat lebih kecil daripada pengorbanan yang harus dilakukan untuk melakukan penelitian itu sendiri, karena selain menuntut biaya yang relatif lebih besar dibandingkan metode lainnya, juga metode ini menurut waktu yang lebih banyak.

\section{Pernyataan Standar Akuntansi Keuangan No.14 tentang Persediaan}

PSAK adalah standar yang harus diikuti dalam pencatatan dan pelaporan akuntansi di Indonesia. PSAK ini merupakan aturan-aturan yang harus ditaati oleh para akuntan agar pelaporan akuntansi di Indonesia ini menjadi lebih efektif.

1. Persediaan

Ikatan Akuntansi Indonesia mengkhususkan pernyataannya mengenai persediaan dalam PSAK No. 14. Ini terdiri dari bagian pendahuluan, penjelasan dan mengungkapkan mengenai persediaan barang dagangan.

2. Pendahuluan

PSAK No.14 bagian pendahuluan memuat tentang tujuan pernyataan, ruang lingkup pernyataan dan definisi persediaan. Pendahuluan ini terdiri dari paragraf 1 sampai dengan paragraf 4

3. Tujuan

Tujuan pernyataan ini adalah mengatur perlakuan akuntansi untuk persediaan. Permasalahan pokok dalam akuntansi persediaan adalah penentuan jumlah biaya yang diakui sebagai aset dan perlakuan akuntansi selanjutnya atas aset tersebut sampai pendapatan terkait diakui.

4. Ruang Lingkup

PSAK No.14 paragraf 2 menyatakan bahwa: pernyataan ini diterapkan untuk seluruh persediaan, kecuali:

a. Pekerjaan dalam proses yang timbul dalam kontrak konstruksi, termasuk kontrak jasa yang terkait langsung (lihat PSAK 34: Kontrak Konstruksi);

b. Instrumen keuangan (lihat PSAK 50: Instrumen Keuangan: Penyajian dan PSAK 55: Instrumen Keuangan: Pengakuan dan Pengukuran);

c. Dikosongkan.

\section{Penelitian Terdahulu}

Wullur (2016) dalam penelitian berjudul Analisis Penerapan Akuntansi Persediaan Berdasarkan Psak No.14 Pada Pt. Gatraco Indah Manado. Hasil penelitian menunjukan secara keseluruhan PT. Gatraco Indah Manado telah sesuai dengan PSAK No. 14 (Revisi 2014), baik dalam metode pencatatan, penilaian, persediaan, pengukuran maupun pengungkapan persediaan.

Lantang (2013) dalam penelitian berjudul Penerapan Metode Penilaian Persediaan Bahan Baku pada PT. Cargill Indonesia (Copra Crushing Plant Amurang). Hasil penelitian menunjukan perhitungan penilaian persediaan yang masuk dalam proses produksi dan persediaan akhir memasukkan harga kontrak dan non kontrak yang mempengaruhi laporan laba rugi perusahaan dimana menghasilkan harga pokok produksi lebih besar dan laba yang lebih kecil.

Hidayat (2015) dalam penelitian berjudul Analisis Sistem Akuntansi Persediaan Bahan Baku Kertas Dalam Upaya Peningkatan Pengendalian Intren (Studi Pada PT. Peruri 
Wira Timur Surabaya). Hasil penelitian menunjukan ditemukan beberapa kelemahan pada sistem akuntansi persediaan bahan baku kertas yang dilakukan oleh PT. Peruri Wira Timur Surabaya. Kelemahan tersebut yaitu terdapat perangkapan tugas dan tanggung jawab yang dilakukan oleh bagian gudang.

Irmayani (2013) dalam penelitian yang berjudul Analisis Akuntansi Persediaan Barang Dagangan pada CV. Kawal Pantai Bintai. Hasil penelitian menunjukan akuntansi persediaan pada CV. Kawal Pantai Bintan belum sesuai dengan PSAK No.14, seperti tidak adanya biaya persediaan, biaya lain - lain dan biaya konversi pada pengukuran persediaan.

Onoja (2015) dalam penelitian yang berjudul Inventory Valuation Practices and Reporting : Nigerian Textile Industry Experience. Hasil penelitian menunjukan metode FIFO memberikan biaya yang realistis sehingga lebih unggul daripada penilaian dengan metode rata - rata di Industri Tekstil di Nigeria. metode FIFO juga lebih dipahami dan diterapkan daripada metode rata - rata.

Bachelino (2016) dalam penelitian yang berjudul Analisis Penerapan PSAK No.14 Terhadap Metode Pencatatan dan Penilaian Persediaan Barang Dagangan Pada PT. Surya Wenang Indah Manado. Hasil penelitian menunjukan metode pencatatan dan penilaian yang diterapkan pada PT. Surya Wenang Indah Manado telah sesuai dengan PSAK No.14 namun perusahaan tidak mencatat biaya konvensi dan lain-lain.

\section{METODE PENELITIAN}

\section{Jenis Penelitian}

Penelitian ini menggunakan pendekatan kualitatif dimana dalam penelitian yang dilakukan bersifat deskriptif yaitu untuk mengetahui atau menggambarkan kenyataan dari kejadiaan yang diteliti sehingga memudahkan penulis mengetahui dan memahami Perlakuan Persediaan Barang Dagangan yang ditetapkan oleh PT.Pertani (Persero) Cabang Sulawesi Utara.

\section{Tempat dan Waktu Penelitian}

Penelitian ini dilaksanakan pada PT. Pertani (Persero) Cabang Sulawesi Utara yang beralamat di Jln. Arnold Mononutu No.3 Wanea. Penelitian untuk penulisan skripsi ini dimulai pada bulan Februari 2017 sampai dengan Mei 2017.

\section{Prosedur Penelitian}

Prosedur penelitian menyangkut langkah-langkah yang dilakukan untuk melakukan penelitian, yaitu sebagai berikut.

1. Melakukan permohonan izin penelitian pada PT. Pertani (Persero) Cabang Sulawesi Utara.

2. Mengetahui struktur organisasi PT. Pertani (Persero) Cabang Sulawesi Utara, serta tugas dan tanggung jawab masing-masing.

3. Mengetahui bagian-bagian yang bertanggung jawab dalam setiap hal yang berhubungan dengan pelaporan keuangan terutama berkaitan dengan persediaan barang dagangan pada PT. Pertani (Persero) Cabang Sulawesi Utara.

4. Mengumpulkan data-data yang berhubungan dengan perlakuan persediaan barang dagangan pada PT. Pertani (Persero) Cabang Sulawesi Utara.

5. Melakukan analisis terhadap data-data yang telah diperoleh dari PT.Pertani (Persero) Cabang Sulawesi Utara

6. Menarik kesimpulan dan saran untuk PT.Pertani (Persero) Cabang Sulawesi Utara.

\section{Jenis Data}

Metode penelitian yang digunakan dalam penelitian ini adalah penelitian kualitatif. Menurut Sugiyono (2016: 1) metode penelitian kualitatif digunakan untuk mendapatkan data 
yang mendalam, suatu data yang mengandung makna, makna adalah data yang sebenarnya, data yang pasti yang merupakan suatu nilai dibalik data yang tampak. Oleh karena itu dalam penelitian kualitatif tidak menekankan pada generalisasi, tetapi lebih menekankan pada makna. Generalisasi dalam penelitian kualitatif dinamakan transferability, artinya hasil penelitian tersebut dapat digunakan ditempat lain.

\section{Sumber Data}

Suharsimi (2013:172) menyatakan yang dimaksud dengan sumber data dalam penelitian adalah subjek dari mana data dapat diperoleh. Menurut Indrawan dan Yaniawati (2014:141) sumber data penelitian terdiri atas data primer dan data sekunder.

1. Data primer adalah sumber data yang langsung memberikan data kepada pengumpul data. Peneliti melakukan wawancara dengan 2 narasumber dari perusahaan.

2. Data sekunder adalah sumber yang tidak langsung memberikan data pada pengumpul data, misalnya lewat orang lain atau lewat dokumen. Peneliti mengumpulkan data - data dari perusahaan yaitu kartu stok persediaan, laporan laba rugi, dan neraca.

\section{Teknik Pengumpulan Data}

Teknik pengumpulan data dilakukan dengan cara:

1. Wawancara, yaitu penulis melakukan serangkaian Tanya jawab secara langsung dengan pihak perusahaan yang berwenang yaitu bagian akuntansi untuk mengetahui lebih jelas mengenai persediaan dan informasi yang berkaitan dengan perusahaan.

2. Dokumentasi, yaitu penelitian yang dilakukan dengan mengumpulkan data - data yang diperoleh dari perusahaan.

3. Observasi pada awal penelitian, yaitu dengan mengadakan tinjauan langsung ke perusahaan yang menjadi objek penelitian mengenai Perlakuan Persediaan Barang Dagangan.

\section{Metode Analisis Data}

Berdasarkan metode pengumpulan data diatas, maka analisa data yang dilakukan adalah analisa deskriptif kualitatif yaitu menganalisa dan membandingkan data-data yang diperoleh dari PT. Pertani (Persero) Cabang Sulawesi Utara dengan PSAK No.14, sehingga dapat memberikan informasi dan dapat ditarik kesimpulan yang lebih luas.

\section{HASIL PENELITIAN DAN PEMBAHASAN \\ 4.1.Hasil Penelitian \\ Jenis - Jenis Persediaan}

PT. Pertani Cabang Sulawesi Utara merupakan perusahaan dagang, maka persediaannya hanya 1 jenis yaitu persediaan barang dagangan. Persediaan barang dagangan pada PT. Pertani (Persero) Cabang Sulawesi Utara meliputi barang yang dibeli dan disimpan untuk dijual kembali dalam kegiatan usaha normal perusahaan.

Produk yang dipasarkan PT. Pertani Cabang Sulawesi Utara yaitu benih, pupuk, alatalat pertanian, dan obat-obatan pertanian. Kegiatan-kegiatan tersebut merupakan upaya PT. Pertani Cabang Sulawesi Utara untuk memenuhi ketersediaan sarana dan prasarana produksi pertanian bagi para petani serta kebutuhan pangan secara merata bagi masyarakat.

\section{Pengukuran Persediaan}

Pada PT. Pertani (Persero), biaya-biaya yang terkait dengan pembelian persediaan adalah biaya pembelian atas persediaan tersebut, biaya lainnya yang secara langsung dapat diatribusikan pada perolehan persediaan barang dagangan sampai barang masuk ke dalam gudang dan siap untuk dijual. 
Dalam pembelian perusahaan didasarkan atas syarat penyerahan barang $F O B$ Destination Point menyatakan bahwa segala beban atau biaya angkut serta tanggung jawab penjual hingga barang tersebut sampai ke gudang perusahaan. Oleh karena itu, perusahaan tidak menjurnal biaya angkut karena biaya angkut sudah melekat pada harga barang yang dibeli, jadi yang dicatat dalam pembukuan perusahaan adalah harga beli barang dagang.

Perusahaan menggunakan 2 metode yaitu metode FIFO dan Moving Average. Karena pada PT.Pertani (Persero) ada persediaan subsidi yaitu benih. Oleh karena itu perusahaan menilai persediaan dengan menggunakan 2 metode. Untuk benih bersubsidi perusahaan menggunakan metode Moving Average sedangakn untuk persediaan diluar benih bersubsidi perusahaan menilai dengan menggunakan metode $F I F O$.

\section{Pengakuan Persediaan}

Pengakuan persediaan pada PT. Pertani (Persero) jika persediaan dijual, maka jumlah tercatat persediaan tersebut diakui sebagai beban pada periode diakuinya pendapatan. PT. Pertani (Persero) mencatat persediaan barang dagangannya dengan menggunakan metode perpetual, yaitu mengelola persediaan dimana arus masuk dan arus keluar persediaan dicatat secara terinci, sehingga perusahaan dapat mengetahui jumlah persediaan yang ada. Dengan penerapan sistem pencatatan perpetual, pencatatan dilakukan secara terus menerus tiap terjadi transaksi persediaan. Persediaan disesuaikan dengan jumlah pemesanan dari konsumen.

Pembelian barang dagangan merupakan transaksi yang menambah persediaan. Barang yang digunakan dalam usaha dagang ini dibeli dari pemasok, disimpan, dan kemudian dijual kepada pelanggan tanpa adanya perubahan pada barang tersebut. Transaksi ini baru dicatatat kedalam buku perusahaan jika faktur pembelian atau barang telah diterima. Jika barang sudah diterima maka, setiap barang dagang diberikan kode nomor barang, lalu di input kedalam komputer atau sistem pencatatan. Dengan menggunakan sistem ini, setiap transaksi akan langsung terproses dan dikelola oleh sistem.

\section{Pengungkapan}

PT. Pertani (Persero) mengungkapkan persediaan barang dagangan melalui laporan laba rugi dan neraca. PT. Pertani (Persero) mencatat persediaan bukan dengan nilai wajar tapi dengan historical cost. Karena perputaran persediaan pada PT. Pertani berjalan dengan normal sehingga perusahaan merasa lebih cocok jika menggunakan historical cost.

Perusahaan mencatat jumlah persediaan yang diakui sebagai beban selama periode berjalan. Perusahaan melakukan cadangan penurunan nilai persediaan barang dagangan mereka, apabila persediaan rusak, kadaluarsa, maupun penurunan kualitas persediian. Maka kebijakan akuntansi PT. Pertani (Persero) akan melakuan pencadangan penurunan nilai persediaan pada akhir tahun dengan melakukan perhitungan fisik (stock opname). Tahap pertama perusahaan akan menjurnal, seperti dibawah.

Persediaan barang rusak

Persediaan

Tahap kedua perusahaan akan menjurnal, seperti dibawah.

Biaya kerugiaan barang rusak

Cadangan penyisihan kerugian barang rusak
Rp. $x x x$

Rp.xxx

Rp. $x x x$

Pencadangan persediaan biasanya $50 \%$ dan bahkan $100 \%$, tergantung pada kondisi persediaan yang mengalami penurunan nilai. Namun PT. Pertani pada saat ini tidak memiliki barang yang mengalami perununan nilai karena tingginya permintaan pelanggan. 


\subsection{Pembahasan}

\section{Jenis - Jenis Persediaan}

Persediaan pada PT. Pertani (Persero) meliputi barang yang dibeli dan dimiliki untuk dijual kembali termasuk, sebagai contoh, barang dagangan yang dibeli untuk dijual kembali. Hal ini telah sesuai dengan PSAK 14 (Revisi 2015).

\section{Pengukuran Persediaan}

Persediaan pada PT. Pertani (Persero) diukur berdasarkan harga pokok ditambah dengan biaya - biaya yang terkait. Biaya - biaya yang terkait adalah biaya pembelian atas persediaan tersebut, biaya bongkar barang masuk gudang. Biaya - biaya ini dibebankan ke harga pokok penjualan sehingga membentuk harga pokok perolehan persediaan barang dagangan tersebut. Oleh karena itu, hal ini telah sesuai dengan PSAK No. 14 (Revisi 2015).

PT. Pertani (Persero) menilai persediaan barang dagangan benih bersubsidi dengan menggunakan metode Moving Averange sesuai dengan kebijakan akuntansi perusahaan. Oleh karena itu, hal ini telah sesuai dengan PSAK No. 14 (Revisi 2015).

Dan untuk barang dagangan diluar benih bersubsidi, PT. Pertani (Persero) menilai persediaan barang dagangan dengan menggunakan metode FIFO (First In First Out), yaitu barang yang masuk pertama harus dikeluarkan pertama juga. Hal ini dikarenakan persediaan barang dagangan mempunyai umur manfaat yang sedikit cepat. Oleh karena itu, hal ini telah sesuai dengan PSAK No. 14 (Revisi 2015).

\section{Pengakuan Persediaan}

Pada PT. Pertani (Persero), persediaan diakui pada saat faktur diterbitkan oleh penjual. Perusahaan mencatat transaksi pembelian berdasarkan tanggal faktur. Dokumen yang terkait dengan pembelian mengisyaratkan bahwa syarat penyerahan barang adalah $F O B$ Destination Point. Faktur yang diterbitkan penjual adalah faktur yang diterbitkan pada tanggal saat persediaan barang dagangan telah sampai di gudang PT. Pertani (Persero). Oleh karena itu, hal ini telah sesuai dengan PSAK No. 14 (Revisi 2015). Pada PT. Pertani (Persero), persediaan yang dijual diakui sebagai beban pada saat periode diakuinya pendapatan atas penjualan tersebut. Hal ini telah sesuai dengan PSAK No.14 (Revisi 2015).

\section{Pengungkapan}

Perusahaan melaporkan nilai persediaan barang dagangan untuk dijual dalam laporan keuangan di dalam komponen aktiva lancar. Oleh karena itu, hal ini telah sesuai dengan PSAK No. 14 (Revisi 2015). PT. Pertani (Persero) mencatat persediaan bukan dengan nilai wajar tapi dengan historical cost. Oleh karena itu, hal ini tidak sesuai dengan PSAK No.14 (Revisi 2015). Perusahaan melakukan pengklarifikasian atas persediaan yang dicatat pada neraca di laporan keuangan. Pengklarifikasiannya dibuatkan dalam catatan atas laporan keuangan perusahaan. Hal ini telah sesuai dengan PSAK No.14 (Revisi 2015). Perusahaan mengungkapkan jumlah persediaan yang diakui sebagai beban selama periode berjalan. Hal ini telah sesuai dengan PSAK No.14 (Revisi 2015). Didalam laporan keuangan PT. Pertani (Persero) pencantuman cadangan penurunan nilai. Hal ini juga telah sesuai dengan PSAK No. 14 (Revisi 2015). Laporan keuangan PT. Pertani (Persero) mengungkapkan pencatatan persediaan diperuntukan sebagai jaminan kewajiban. Hal ini telah sesuai dengan PSAK No.14 (Revisi 2015).

\section{KESIMPULAN DAN SARAN Kesimpulan}

Sesuai dengan hasil penelitian dan pembahasan yang telah disajikan pada bab sebelumnya, maka peneliti dapat menyimpulkan bahwa : 
1. Pengungkapan laporan keuangan pada PT. Pertani (Persero) masih ada beberapa hal yang tidak sesuai sesuai dengan Pernyataan Standar Akuntansi Keuangan No. 14 (Revisi 2015). Perusahaan tidak mencatat persediaan dengan menggunakan nilai wajar melainkan dengan historical cost.

2. Persediaan adalah aset yang tersedia untuk dijual dalam kegiatan usaha biasa. Persediaan meliputi barang yang dibeli dan dimiliki untuk dijual kembali, pada perusahaan dagang telah sesuai dengan Pernyataan Standar Akuntansi Keuangan No. 14 (Revisi2015).

3. Biaya persediaan diukur pada mana yang lebih rendah antara biaya perolehan dan nilai realisasi neto. Biaya persediaan dihitung dengan menggunakan rumus biaya masuk pertama keluar pertama (MPKP) atau rata-rata tertimbang. Entitas menggunakan rumus biaya yang sama terhadap seluruh persediaan yang memiliki sifat dan keuangan yang sama. Untuk persediaan yang memiliki sifat dan kegunaan yang berbeda diperkenankan. Pengukuran persediaan pada PT. Pertani (Persero) telah sesuai dengan Pernyataan Standar Akuntansi Keuangan No. 14 (Revisi2015).

4. Jika persediaan pada PT. Pertani (Persero) dijual, maka nilai tercatat persediaan tersebut harus diakui sebagai beban pada periode diakuinya pendapatan atas penjualan tersebut. Pengakuan persediaan pada PT. Pertani (Persero) telah sesuai dengan Pernyataan Standar Akuntansi Keuangan No. 14 (Revisi2015).

\section{Saran}

1. Perusahaan sebaiknya menggunakan konsep nilai wajar agar perlakuan persediaan pada PT. Pertani (Persero) Cabang Sulawesi Utara sesuai dengan PSAK No.14 (Revisi 2015).

2. Perusahaan sebaiknya melakukan perhitungan fisik dengan mencocokan dengan pencatatan persediaan perusahaan, disarankan untuk dicocokan setiap bulan, untuk menghindari penyelewengan ataupun kecurangan atas persediaan.

3. Tingkat stok ekstra (safety stock) agar dipertahankan supaya jangan terjadi kekosongan persediaan saat banyaknya permintaan dari pelanggan.

4. Hasil print out kartu persediaan yang ada di program akuntansi sebaiknya dirincikan untuk kolom pembelian dan pejualan serta stok akhir.

\section{DAFTAR PUSTAKA}

Anwar, Nurul dan Herman Karamoy, 2014. Analisis Penerapan Metode Pencatatan dan Penilaian terhadap Persediaan Barang menurut PSAK No.14 pada PT. Tirta Investama DC Manado. Jurnal Emba Vol.2 No.2

Barchelino, Rivaldo. 2016. Analisis Penerapan PSAK No.14 Terhadap Metode Pencatatan dan Penilaian Persediaan Barang Dagangan Pada PT. Surya Wenang Indah Manado. Universitas Sam Ratulangi. Manado. Jurnal EMBA Vol.4 No.1 Maret 2016.

Hery, S.E., M.Si. 2013. Akuntansi Dasar 1 dan 2. PT. Gramedia Widiasarana Indonesia. Jakarta.

Hidayat, Divo Vito. 2015. Analisis Sistem Akuntansi Persediaan Bahan Baku Kertas Dalam Upaya Peningkatan Pengendalian Intren (Studi Pada Pt. Peruri Wira Timur Surabaya). Universitas Brawijaya. Malang. Jurnal Administrasi Bisnis (Jab) Vol.16 No. 1 September 2015.

Ikatan Akuntan Indonesia. 2015. Pernyataan Standar Akuntansi Keuangan No.14 (Revisi 2015) - Persediaan. Jakarta.

Lantang, Tesalonika. 2013. Penerapan Metode Penilaian Persediaan Bahan Baku pada PT. Cargill Indonesia (Copra Crushing Plant Amurang). Universitas Sam Ratulangi. Manado. Jurnal EMBA Vol.1 No.3 Juni 2013.

Mardiasmo. 2014. Akuntansi Keuangan Dasar 2. Edisi 2. Yogyakarta. 
Pontoh, Winston. 2013. Akuntansi Konsep dan Aplikasi. Halaman Moeka. Manado.

Rudianto. 2012. Pengantar Akuntansi Konsep \& Teknik Penyusunan Laporan Keuangan. Erlangga. Jakarta.

Santoso, Iman. 2010 Akuntansi Keuangan Menengah. PT. Rafika Aditama. Bandung.

Sugiono. 2010. Metode Penelitian Bisnis (Pendekatan Kuantitatif, Kualitatif dan R\&D). Alfabeta, Bandung.

Wullur, Tesalonika. 2016. Analisis Penerapan Akuntansi Persediaan Berdasarkan Psak No.14 Pada Pt. Gatraco Indah Manado. Universitas Sam Ratulangi. Manado. Jurnal Going Concern Vol 11, No 1 (2016).

Yahya, Uthman Abdullahi. 2015. Inventory Valuation Practices and Reporting : Nigerian

Textile Industry Experience. Mediterranean Journal of Social Sciences. Department of Accounting \& Finance, Northwest University, Kano. 